\title{
Overbooking And Overselling: Between A Legal Trade Mechanism And A Crime Of Fraud
}

Silvia Valmaña Ochaíta, Ph.D., University of Castilla-La Mancha, Spain

\begin{abstract}
The different operators, both transport and hotel, are used to perform a number of practices which, by its importance have been aim of regulation of international and national legislators. Economic interests from both parties companies and the customers, enhance the need to make more flexible traditional contracts of sale by establishing mechanisms for the resign of the contract by the customer, with greater or lesser penalties, and, in the other hand, the possibility that the number of booked seats or rooms would be greater than the initially available. However, the boundaries between licit, illicit operations and criminal behavior occur occasionally blurred. The purpose of this work is to establish some guidelines to define clearly the border between legal, illegal, or criminal conduct, and the response that law gives in each case.
\end{abstract}

Keywords: Overbooking, law and economic interests

\section{INTRODUCTION}

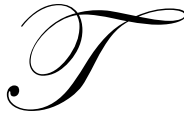

he tourism is a phenomenon that has come developing throughout both last centuries. The journeys that came relating throughout History usually had an administrative or religious character. From the $19^{\text {th }}$ century, due to the conditions created by the Industrial Revolution, the tourism begins to have the modern concept that subsists nowadays. Its importance in the economic and social sphere is unquestionable, to the point to give rise to an agency of the United Nations, the Word Tourism Organization (UNWTO), which indicates in relation to its object that "Over the decades, tourism has experienced continued growth and deepening diversification to become one of the fastest growing economic sectors in the world. Modern tourism is closely linked to development and encompasses a growing number of new destinations. These dynamics have turned tourism into a key driver for socio-economic progress".

Nevertheless, such development has taken associated, in the last decades, the increasing demand of these services by the consumers, whom the appearance of certain mechanisms on the part of the tending tourist companies has favored to optimize its resources and capacities, as much in the scope of the transport like in the hotel establishments.

The difference between the allowed practices and the prohibited ones, when no fraudulent, is not always clear. A first review for differences of others will be to determine with clarity the concepts of double selling, overbooking and overselling, and this way to analyze if the different commercial practices are located in some of the referred categories or if, on the contrary, the limits have exceeded the same ones and we are in the land of the criminal excellent conducts. First, we can define the double selling like the fact that a subject one sells a same thing to different purchasers. But in spite of the apparent simplicity of this definition, we are talking about a complex legal reality that, sometimes, can be confused with other figures that take prepared diverse legal consequences.

The double selling takes shelter in the Civil Code like an abnormal assumption in which the preference of the purchasers is regulated in sequence to establish the transmission of the property in a situation in which the vendor acts of opposite form to the good faith. The article 1473 of the Civil Code establishes that "if a same thing 
had been sold to different purchasers, the property of the thing will transfer the person who first has taken possession from her with good faith, if personal property. If real estate, the property will belong to the purchaser who before has registered it in the Registry. When there is not inscription, the property will belong to that is first in the possession of good faith; and, lacking this one, to that presents title of older date, whenever there is good faith". Secondly, it agrees to emphasize that we are in front of the legal treatment of the double selling in the civil field, referred the objects that are in its scope (properties), and with the necessary requirements that gives the double selling the legal consequences that the Civil Code attributes to such double selling. This rule is referred not much to the vendor who has made the double selling but the purchaser of good faith, and that necessarily he will have to see frustrated his expectations of acquisition. These legal consequences for the vendor require, on a hand, by the satisfaction of the purchaser's rights, that cannot acquire the property doubly sold, and that would be governed by the general rules of compensation of the damage (CANO, 2005), independently of the enthusiastic debates on acquisition. Another thing will be the criminal consequences that can be derived from the double selling (BAJO, 2004).

The Criminal Law studies the double selling between the cases of fraud (HUERTA, 1980), establishing a clear dividing line between the civil malice and the mens rea in the criminal scope, within the category of the criminalized civil contracts that as much attention have received in the Spanish jurisprudence (CASTIÑEIRA, M.T./CORCOY, M./SILVA, J.M., 1985). But next to these elements, the sphere of our study talks about the tourist sector, sector this whose development has taken place recently. The modernity of the tourist phenomenon has taken prepared a new regulation that, sometimes, presents a special difficulty to make compatible the application of figures designed for the reality of another time. In this sense, we can indicate that the Civil Code regulation of the double selling bases on the continuous reference to the double selling of properties. In the tourist sector, on the contrary, which "is sold" in most of the cases is not another thing that a service, and therefore we were with one first difficulty that appears insurmountable, to solve the own similar assumptions of this sector, beyond general a interpretative criterion that, on the other hand, is well known in the Civil Law, as is the principle Prior Tempore, Potior Iure.

\section{THE CRIMINAL TREATMENT OF THE DOUBLE SELLING IN THE TOURIST SECTOR.}

The incrimination of the double selling in the Criminal Code appears in the Reformation of 1983, when in the $2^{\text {nd }}$ paragraph of the article 531, the Criminal Code went to incorporate, between the improper fraud, the conduct of who "transfer two or the more times" a property or who "burden it or rent it after to have transferred". The Criminal Code observes the double selling like a specific assumption of fraud in the article 251.2. This rule is making reference clearly, as in the Civil Law, to the double selling of properties, furniture or buildings, but not the services. It's more clear in the scope of the Criminal Law, in which the exigency of the legality principle acquires a strict interpretation of the legal rules, with express interdiction of the analogy in the article 4 of the Criminal Code, when it establishes that "the criminal laws will not be applied specifically to cases different from the included ones in them".

Without the possibility of applying the only express reference to the double selling in the Spanish criminal ordering, we will have to go to the general category of the fraud crime to find the answer in front of the most serious cases of fraud, according to settles down in the article 248.1 of the Criminal Code: "Commit fraud who, with profit mind, will use enough deceit to produce error in another one, inducing it to make a disposition act in own or other people's damage".

In order to the systematization of the cases of double selling or similar, in which a criminal fraud within the own operations of the tourist sector can take place, we can differentiate two great categories in which these criminal consequences can occur more commonly. We are talking about to the cases of "double selling" of the advantage in turn of tourist buildings, colloquially known like time-sharing, and the cases of "double selling" in contracts of reserve of made tourist seats between entrepreneurs (VALMAÑA, M./VALMAÑA, S., 2010). In both cases, we were within which it is known with the name of contracts or criminalized legal businesses, of great variety of content, but which it stops to enter the type of fraud must have specific characteristics. That is to say: 
- $\quad$ The division of the criminal malice (mens rea) and the civil malice, in the crimes against the patrimony settle down in the typicity, so that only if the agent behavior is considered inside the criminal rule of the fraud crime, is possible to punish action, not supposing it to criminalize all contractual breach, because the Legal Ordering establishes ways to restore the empire of the Law when it is violated by purely civil vices (SCS, November, the $17^{\text {th }}, 1997$ ).

- The malice must be preexisting, this is, and the perpetrator of the crime ab initio has intention to breach the contract, simulating an appearance of hiring with the only intention to take advantage of the fulfillment of the victim (Vide, as most important Supreme Court Sentences in this matter: SCS, June, the $20^{\text {th }}, 1998$; SCS, March, the $16^{\text {th }}, 1995$; SCS, February, the $26^{\text {th }}, 2001$; SCS, December, the $11^{\text {th }}, 2000$; and SCS, January, the $20^{\text {th }}$, 2004).

- $\quad$ They must occur the rest of the elements that characterize to the fraud: the sufficient deceit; the error of the victim, causally linked to the deceit, and that takes place in spite of diligence of the victim; and finally, the patrimonial disposition that causes an economic damage to the victim or to other people.

\section{The double selling in the advantage in turn of tourist buildings}

The jurisprudence on the cases of fraud in the time-sharing has been plentiful, although it is certain that with the appearance of a formal regulation of these contracts (Vide Spanish Time-Sharing Law 42/1998, December, the $15^{\text {th }}$; European Union Directive 2008/122/CE, January, the $14^{\text {th }}$; Resolution of July, the $4^{\text {th }}$, 2002, European Parliament) the criminal jurisdiction has seen reduced its scope of action, like, on the other hand, must be. Nevertheless, the similar cases of fraud to the double selling in the field of the time-sharing of tourist buildings have not had a great jurisprudential development, as either a specific attention on the part of the Spanish criminal doctrine. On one hand, these cases usually have a great technical complexity, affect a great amount of subjects and the time from the beginning of the investigating activity of the fraud to its conclusion with a sentence signs is, without a doubt, very expanded. Thus, frequently the judicial reality of some cases with a great media repercussion barely passed the phase of attribution of the competence for the instruction, whereas in the Supreme Court we were some sentence on matters that we could describe as minors, by the number of affected, and on facts previous to the take effect of the Law of Time-Sharing. Among these sentences, it deserves to emphasize the Supreme Court Sentence (SCS, in advance) 166/2006 February, the $22^{\text {nd }}$, by which the representative of mercantile Holitime Internacional SA, and to the administrator of Destination Bleu Soleil SL, are condemned by coming to formalize diverse deprived contracts of transaction with different people, in which Destination Bleu Soleil sold to the victims stocks of Holitime International, acquiring the purchasers a participation of the real estate property of Holitime International, SA, and consequently the right to occupation and the use and enjoys these real estate by a determined time, as well as to being to comprise of the program of interchange of rights of use of tourist residence supported by the company Interval International (on the operation of the interchange of timeshare, vide the Web Page of Interval International). It's unnecessary to say that the expectations of the purchasers about the contracts fulfillment were absolutely seen failed. The summary of the facts is the following one: the contact with the buying potentials through an aggressive commercial strategy made in the street of a denominated "stratch-and-win game" with assured prize that they would have to gather in the premises of the administrator of Destination Bleu Soleil SL. There, through diverse explanations, the clients were persuaded for the sign of contracts, sometimes at that same moment. The certain thing is none of the companies has any property title of any building, and "Mercantil Holitime International, SA was not associate to the Program of International Holidays Interchange, Interval International España, SA, The unique relationship with this famous Program was in 1994, when one of defendants applied for the affiliation to the Program of Interval Interchange of the tourist complexes Los Jazmines and Hotel Residence Carlton Playa, in Denia, granting the provisional affiliation sending in a next future a legal report signed by a lawyer in which were developed the aspects relative to the nature of the rights of timesharing to transmit as well as referring to the legal structure of the complexes whose affiliation was asked for. This provisional affiliation was notified to him to the defendant by a letter of date 1-26-1995, in which it was indicated that to obtain the total affiliation to Interval, he would have to provide greater information on the complexes, including the mentioned legal report. The defendant did not send to Interval the required information or the legal report, reason why the complexes the Jazmines and Residence Hotel Carlton Playa cannot offer the condition of individual partner of Interval International to the purchasers of weeks in such establishment, nor have been registered totally in the alluded Program of Interchanges. Eleven deprived contracts were formalized, and the amount of money obtained with them was completely incorporated to the patrimony of the defendants. The victims have not been able to use and to enjoy the legitimate 
right acquired by virtue of the contract of stock trading, nor that has returned to him of the amount which they gave in such concept.

\section{The contracts of reserve of tourist seats made between entrepreneurs}

We have seen a paradigmatic case of fraud on the selling of hotel seats to individuals, and now is the moment to occupy, at least briefly, on selling a greater number of tourist seats. Of course, we mean the original contract, made between entrepreneurs. The Sentence of the Provincial Court of Zaragoza, n. 113/2002, April the $19^{\text {th }}$, is a very good example of this: "the defendant pretended to have more hotel seats which in fact he had, which induced to error to New line and gave rise to the hiring of the reserves, and, in addition, the few seats which had Diego M. was sold to several clients. It fulfilled the contract with the plaintiff during the low season, but in the summer, with the evidence of a great affluence of tourists, he could not fulfill his obligation. Nevertheless, he extended in annexed to the contract, July, the $3^{\text {rd }}, 1997$, that aggravates the conduct of the defendant, because he pretended possibilities of business in the month of July what induced to New Line to the extension of the pact with a payment of seven million pesetas more; possibilities that did not respond to the reality because there were an overselling of residential seats with several clients, which constitutes a fraud crime...".

As we can observe, the requirements that must concur in a legal business to have the fraud consideration, as criminalized civil contract, are also fulfilled in this case.

In this moment it is necessary to remember that the fraud requires as essential element the concurrence of the deceit that must be sufficient, just as precedent or concurrent with the act of disposition of the victim, which constitutes the consequence or effect of the deceptive action. The deceit has been widely analyzed by the jurisprudential doctrine, identifying it as a type of scheme, maneuvers or machination, mendacity, fabrication, invention or artifice, which determines the patrimonial advantage in damage of other person, and thus it has understood extensive the legal concept to "any lack of truth or whatever simulation", that determines the victim to give a thing, money or benefit, that in another way, had not made (SCS 1.27.2000). The deceit must be enough to produce error in others (SCS. 5.29.2002) what means that it is sufficient in a double sense: first to go beyond the frontiers of the civil illicit and to penetrate in the criminal scope; and secondly, that the action must be adequate, important, and appropriated to produce the mistake. All this question means that, to be a criminal fraud, is not enough a poor, fantastic or inaccessible mistake or misunderstanding or a blatant, because it's unfit to move the will of the people, according to the social and cultural atmosphere in which they are (SCS 2.2.2002). At this point it is convenient to remember the theory of the criminalized legal businesses and the distinction between civil and malice. The Supreme Court Sentence n. 17, 1197 indicates that: "the dividing line between the criminal malice and the civil malice in the crimes against the patrimony, locates the typicity solely, so that if the conduct of the agent is included in criminal rule of the fraud crime, not supposing it to criminalize all contractual breach, because the legal ordering establishes remedies to restore the empire of the Law when there is a violation by purely civil vices...".

\section{CONCLUSION}

It is important to remember that the Criminal Law is inspired by a basic single principle, the minimal intervention principle, which configures it as the last ratio to safeguard the social order. Such principle takes aim at the necessity to establish the less invasive way to correct the deviations of the due behavior. This is the reason for a smaller scope of Criminal Law, in general, and in particular in this matter. Overbooking and overselling belong to the civil sphere, and normally they stay in this field. Only in the most serious cases, if they could be described as a fraud crime, the Criminal Law will be applicable.

\section{AUTHOR INFORMATION}

Silvia Valmaña Ochaita PhD in Law and Degree in Law by University of Alcalá de Henares. Associate Professor at Public and Company Law Department. Faculty of Social Sciences of Cuenca. University of Castilla-La Mancha (Spain). E-mail: Silvia.Valmana@uclm.es.

Research Interest: Penitentiary Law, Women and Law, Patrimonial and Economic Crimes, Tourism, Educational and DNA on Trial. 


\section{REFERENCES}

1. Bajo, M. (2004): "Tipos específicos de estafa", in Los delitos de estafa en el código penal. Available http://vlex.com/vid/296271

2. Cano, J. I. (2005): "La doble venta: una situación de pendencia". Bosch Editor. Available http://vlex.com/vid/aspectos-institucionales-277749

3. $\quad$ Castiñeira, M.T./Corcoy, M./Silva, J.M. (1985): "La reforma del art. 531 del Código penal", La Ley, IV. Madrid

4. $\quad$ Huerta, S. (1980): "Protección penal del patrimonio inmobiliario", Civitas. Madrid.

5. Valmaña, M./Valmaña, S. (2010): "Reflexiones en torno a la doble venta en el sector turístico", in Investigaciones, métodos y análisis del turismo. Septem Ediciones. Oviedo. 
NOTES 